Relations industrielles

Industrial Relations

\title{
Bulletin social des industriels
}

\section{Gaston Cholette}

Volume 5, numéro 1, septembre-octobre 1949

URI : https://id.erudit.org/iderudit/1023275ar

DOI : https://doi.org/10.7202/1023275ar

Aller au sommaire du numéro

Éditeur(s)

Département des relations industrielles de l'Université Laval

ISSN

0034-379X (imprimé)

1703-8138 (numérique)

Découvrir la revue

Citer cet article

Cholette, G. (1949). Bulletin social des industriels. Relations industrielles /

Industrial Relations, 5(1), 10-10. https://doi.org/10.7202/1023275ar

Tous droits réservés @ C Département des relations industrielles de l’Université Laval, 1949
Ce document est protégé par la loi sur le droit d'auteur. L'utilisation des services d'Érudit (y compris la reproduction) est assujettie à sa politique d'utilisation que vous pouvez consulter en ligne.

https://apropos.erudit.org/fr/usagers/politique-dutilisation/ 


\section{Reviews an Industrial Relations}

With the aim of giving greater service to its readers and of meeting more fully the requirements of a university publication, the «Industrial Relations Bulletin» in this number is undertaking to present the principal reviews in French and in English on labour relations.

The method adopted provisionally consists of drawing attention to two or three reviews at a time, making, grosso modo, a recapitulation of the issues of the preceeding year. It is not, as we see it, a question of articles on reviews properly speaking, where we would indicate and analyse the most important recent studies.

The editors of the Bulletin hope that this venture will please, and that, in spite of the inevitable imperfection of the present form, readers will find here much to their profit.

\section{NDUSTRIAL AND LABOUR RELATIONS REVIEW}

«Industrial and Labour Relations Review» is a quarterly publication of about a hundred and fifty pages prepared by the New York State School of Industrial and Labour Relations, Cornell University, Ithaca, N.Y.

Although it has had but two years of existence, it is certainly one of the best-known of the American Journals dealing with labour relations which it approaches from all aspects. Each number contains four or five basic articles, a section called «Discussions and communications», a documentary part, a list of recent publications very well drawn up and divided into special categories, book reports, news and notes.

The present report deals with the four numbers of volume two, namely those of October, 1948, of January, April and July, 1949. In certain of these issues many articles deal with a common theme

That of October, 1948, contains many interesting studies on the reform of structure in the enterprise. Here are the titles of the principal articles of this installment: * Union Management Co-operation in the Millinery Manufacturing in the New York Area », « Profit Sharing under Collective Bargaining », «Economic and Legal Projects of Profit Sharing Plans», «The Small Business Enterprise and the Management Prerogative Issue ».

This last article was written by J. G. Turnbull, a member of the «Social Science Research Council », following an enquiry made in twenty-four enterprises. The author enumerates and classifies the various series of opinions and attitudes of employers concerning the tendency of workers' associations towards a closer and closer integration in the enterprise by sharing in the ownership, the management and the profits.

The author does not himself give an opinion - at least he tries no to - but he shows as objectively as possible the result of his interviews with the employers' representatives.

In concluding his article the author makes some suggestions on the forms of employer-employee co-operation. This study faithfully reflects the attitude of American heads of industry towards the problems of ownership and authority in the enterprise.

Two of the articles in the issue of January, 1949, treat of productive capacity. One of them is entitled «Union-Management Co-operation and Productivity \$.

In the installment of April, 1949, three of the four articles deal with current problems of labour legislation.
Lastly, the number of July, 1949, contains studies on the economic function of strikes, the ciosed shop and personnel direction.

The subscription price for the review is $\$ 4.00$ a year.

G. C.

\section{BULLETIN SOCIAL DES INDUSTRIELS}

The Bulletin social des industriels 》 is a monthly review of about forty pages published by the \& Association des patrons et ingénieurs catholiques de Belgique ».

As with the Association of which it is the official organ, the primary aim of this publication is to make Catholic employers aware of their responsibilities and of their social function and also to search out formulae for applying the social doctrine of the Church. It is not a mouthpiece for apologists but an instrument for enlightning of the employers' point of view.

We frequently find here advanced and extremely original studies on such subjects as the following: * The Authority of the Enterprise », The Family Wage and the Opinion of the Encyclicals », Economy of Exchange and Controlled Economy », *What must we Understand by Enterprise », «Industrial Relations and Social Psychology », etc.

Side by side with these theoretical works, are found articles describing and commenting on certain interesting employer-employee experiences, for example, « Some experiences in going further than the Salary System 》, «An Experience in Sharing in Savings $\gg$, etc.

The contributors to the Bulletin social des industriels are usually university professors or heads of wellknown enterprises, which bestows upon it great theoretical and practical value.

Each number contains an editorial, two or three important articles and various reports. There is almost always a column of news and one of information. In most of the numbers there are also excerpts of employers' study sessions.

The \& Bulletin social des industriels is addressed particularly to Catholic employers. But, the subjects which is treats and the fact that it deals with them in the context of a country where the application of the social doctrine of the Church has been most liberal and most original, are of a nature greatly to interest all those who ardently and sincerely seek examples of and formula for the reform of structure in enterprise, in profession and in the nation.

One can subscribe to the \& Bulletin social des industriels $\gg$ by sending the sum of 300 francs to the Secrétariat général de l'Association des patrons et ingénieurs catholiques de Belgique, 17, rue du Gouvernement provisoire, Bruxelles.
G. C. 